\title{
Physiological Parameters of Salt Tolerance in Different Genotypes of Oats (Avena sativa L.)
}

\author{
Kamaljeet Kaur* and Namarta Gupta \\ Department of Botany, Punjab Agricultural University, Ludhiana, Punjab, India \\ *Corresponding author
}

\section{A B S T R A C T}

\begin{tabular}{|l|}
\hline Ke y w o r d s \\
$\begin{array}{l}\text { Oat, Salt stress, } \\
\text { Germination } \\
\text { percentage, Seed } \\
\text { vigour, Avena } \\
\text { sativa }\end{array}$ \\
\hline Article Info \\
\hline $\begin{array}{l}\text { Accepted: } \\
\text { 20 August } 2020 \\
\text { Available Online: } \\
\text { 10 September } 2020\end{array}$ \\
\hline
\end{tabular}

Eight genotypes of oats were screened under different salt stress levels $(25,50,75$, $100,125,150,175$ and $200 \mathrm{mM}$ ). The effect of salt stress on physiological characteristics of eight oat genotypes (Kent, OL-10, OL-1862, OL-1869, OL-125, OL-1966, OL-1876, OL-1895) cultivated under salt stress conditions was investigated in this study. The experiment was conducted in triplicates in the Punjab Agricultural University, Ludhiana. The results show that the percentage germination of seeds declined significantly beyond 100 and $125 \mathrm{mM}$ of $\mathrm{NaCl}$ in most of the genotypes. These genotypes showed a marked decline in shoot length, root length, seed vigour I, seed vigour II, dry weight. The varieties could be divided into two groups based on the decrease in shoot length, root length at $100 \mathrm{mM}$ which were comparatively sensitive and comparatively tolerant.

\section{Introduction}

Salt stress is a main abiotic stress or affects the crop production. Salinity mainly affects the more than $6 \%$ of the worlds total land area (Gao et al., 2016). According to other report, $7 \%$ of the land region is affected by salt stress (Neto et al., 2006). Salinity of soil may be attributed to the seepage from Rajasthan feeder canals and appears to be the cause for the development of water logging and salinity in these areas. Salinity affects crop development by affecting many physiological, biochemical and metabolic processes. Salt stress affects the different development processes which include photosynthesis, ion regulation, water relations, etc (Ashraf 2004). Salinity, which not only affects crop physiological, morphological, and biochemical processes, but also germination of seedling, development with nutrient/water uptake in oat (Willenborg et al., 2005). High concentration of soil salinity is difficult for roots to take up water and it can be toxic within plant cells (Zhang et al., 2018).

Oat is known as moderately salt tolerant, however it is more sensitive to salt stress as compared to other cereals like barley and wheat. Salt stress has 3 possible effects on 
plants which are as (i) reduction in water potential, (ii) toxicity of any $\mathrm{Na}+$ and $\mathrm{Cl}$ absorbed and (iii) intrusion with the absorb of necessary nutrients. By changes in salt ion concentration, kind of salt present, or kind of plant species, the fresh and dry weights of the shoot system are affected either negatively or positively (Memon et al., 2010). In Oat, Total leaf area, dry weight of shoot decreased by salt stress (Zhao et al., 2017). Salinity amount can effect numerous process in plants, which includes the photosynthesis regulation, balance of ions (Prisco et al., 2007). Propagation of salt-tolerant oats has been restricted by many factors, such as the lack of a standard, which is effective method for evaluate salt tolerance (Talei et al., 2013). Germination is a necessary phase of vegetation and opposition against salt stress during the germination is very significant for stability. Germination proportion slowly decreased in all oat cultivated plants as the amount of salinity increased from 25 to 100 mM (Chauhan et al., 2016).

This study dealt with the analysis of salt tolerant, salt moderant and salt sensitive oat varieties. $\mathrm{NaCl}$ as a neutral salt is applied as stress treatment to oat seedlings to talk over the salt tolerance procedure and adaptability under $\mathrm{NaCl}$ stress (Zhanwu 2015).

\section{Materials and Methods}

Oat seed was collected from fodder section of department of Plant Breeding and Genetics, Punjab Agricultural University, Ludhiana. For each treatment ten seeds were counted and disinfected in this experiment. At first, the entire Petri dishes were cleaned with ethanol. Oat seeds were surface sterilized by $0.1 \%$ solution of mercuric chloride, followed by thorough washing by distilled water to avoid any fungal infection. This study work was performed at the laboratory of the Botany Department of Basic Sciences and Humanties College, Punjab Agricultural University,
Ludhiana. We used $\mathrm{NaCl}$ salt with nine concentrations of $0,25,50,75,100,150,175$ and $200 \mathrm{mM}$. To stimulate salinity stress, the germination paper in petri dishes was moistened with solutions of different salinity levels (Control, 25mM, 50mM, 75mM and $100 \mathrm{mM}, 125 \mathrm{mM}, 150 \mathrm{mM}, 175 \mathrm{mM}$ and $200 \mathrm{mM} \mathrm{NaCl}$ ). The petri dishes were placed in an incubator at $25^{\circ} \mathrm{C}$ and $60 \pm 15 \%$ relative humidity for 14 days to record the effect of salinity on germination parameters.

During the experiment, the germinated seeds were counted each day at a certain time of the daytime. At the end of the experiment (after 12 days), the no and length of root and shoot, fresh and dry weight of root and shoot (oven dried for $72 \mathrm{hr}$ at $70^{\circ} \mathrm{C}$ ) and the no of normal and abnormal seedlings were measured. Seedlings having dead root tips as well as dead or severely distorted cotyledons were considered as abnormal plants.

\section{Percent Germination}

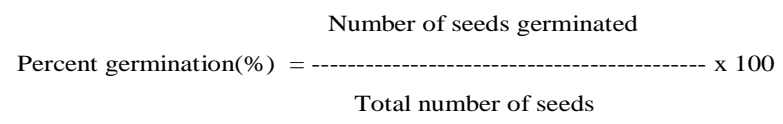

\section{Root length (cm)}

On 14th day of germination five normal seedlings for each treatment were chosen from the germination test for measuring the root length. Root length was measured from the collar region to the tip of root. Average root length of five seedlings was computed and expressed in centimetres.

\section{Shoot length $(\mathrm{cm})$}

For measuring shoot length, previous five seedlings was used which was used for the root length measurement. The length of shoot was measured from the collar region to the point of attachment of cotyledons. The average of five seedlings was computed and expressed in centimeters. 


\section{Seedling Dry Weight (mg)}

For the calculation of seedling dry weight, randomly five normal seedlings were taken and dried using oven at $110^{\circ} \mathrm{C}$ for 17 hours and their dry weight had been recorded by using weighing balance and average weight was computed and expressed in milligrams.

\section{Vigour Index (VI)}

Vigour index of seeds were calculated as suggested by (Abdul Baki's Anderson 1973).

Vigour Index I = Germination (\%) x Seedling length $(\mathrm{cm})$

Vigour Index II = Germination (\%) $\mathrm{x}$ Seedling dry weight $(\mathrm{g})$

Epicotyl length of seedlings were measured by using centimetre scale.

\section{Results and Discussion}

Overall, the salt stress reduced the growth in all varieties, while OL-10 variety showed sensitivity, Kent Variety showed tolerance and OL-1862 was moderate for almost all parameters. By increasing concentration levels the germination of seed and other traits decreased. The maximum inhibitory effect was seen in $200 \mathrm{mM}$.

\section{Percentage Germination (PG)}

Seed germination and seedling growth are critical determining for seedling growth during the initial stages of life. By increasing concentration the percentage germination was decreased to $0 \%$ at $200 \mathrm{mM}$ concentration. At $75 \mathrm{mM}$ and $100 \mathrm{mM}$, the genotypes showed a differential response to salinity stress. The decline in percentage germination varied from 96 to 49.3. On the basis the genotypes could be divided into comparatively salt sensitive, salt moderate and salt tolerant. It decreased from 90 percent to 0 percent in OL-10 genotype thus making it salt sensitive and 100 percent to 26.7 percent in Kent genotype, as salt concentration increased from $25 \mathrm{mM}$ to $200 \mathrm{mM}$ thus making it salt tolerant (Table 1).

This reduction in the percentage of seeds germinating induced by an increase of salinity stress has been described by numerous authors (Akbarimoghaddam, 2011; Zhang, 2013; Kumar 2014; Chauhan, 2019; Berk and Ozkan, 2016). By the increase of salinity level, the reduction in germination was possibly due to the reduced soluble osmotic potential, high toxic ions and seed nutrient imbalance (Abbasian and Moemeni, 2013). It is also assumed that in addition to toxic effects of certain ions, higher concentration of salt reduces the water potential in the medium that hinders water absorption by germinating seeds and thus decreases germination (Maas and Nieman, 1978).

\section{Length and weight of root and shoot (SL, RL, SRDW)}

The root and shoot lengths are the most important parameters for salt stress because roots are in direct contact with soil and absorb water from soil and supply it to the rest of the plant. So, root and shoot length provide an important indication plant response to salt stress (Jamil et al., 2006). The results showed that the Major decline of shoot length was observed in all the genotypes at $200 \mathrm{mM}$ as compared to control. Differential response was seen at 75,100 and $125 \mathrm{mM} \mathrm{NaCl}$ concentration and the decline in shoot length range varied from 18.7 percent to 73.9 percent from 75 to $100 \mathrm{mM}$ salt concentration in different oat genotypes. In comparatively sensitive genotypes, the decrease was more than 50 percent at $100 \mathrm{mM}$. Drastic changes were observed at $100 \mathrm{mM}$ salt concentration. In OL-10 shoot length reduced by 100 percent at $200 \mathrm{mM}$ making it comparatively salt sensitive whereas with a decrease of only 80.6 
percent at $200 \mathrm{mM}$, Kent was considered as comparatively salt tolerant genotype.

The maximum root and shoot lengths were recorded in control treatment (Table 2 and Table 3). However, there occurs more progressive and linear decreases in roots as compared to shoot length with increase in soil salinity levels. Root length decreased gradually as oat seedlings were exposed to salt stress. In OL-10 root length decreased by 36.2 percent at $100 \mathrm{mM}$ salt concentration. In Kent decline was 28.4 percent at $100 \mathrm{mM}$ salt concentration and in OL-1876 a decrease of 26 percent was observed at $100 \mathrm{mM}$ salt concentrations. At higher salinity levels, there occurs decrease in root hairs as there is no sufficient energy for formation of new organs. Similar results were seen in barley seedlings by (Agami, 2014).

The decrease in shoot and root growth may be due to toxic effects of the salt used and unbalanced nutrient uptake by the seedlings. Root length and shoot length decreases with the increase in salinity level that may be due to slowing down the water absorption by the plants (Demir and Arif, 2003).

The increase in root to shoot ratio or decrease in shoot to root ratio is a general response to salt stress, related to factors linked with water stress (osmotic effect) rather than a saltspecific effect (Hsiao, 2000). Normally, the reduction in seedling length, due to the increase in the salt concentration, are caused by physicochemical effects or by osmotictoxic salts that occurs in salty solutions. Salinity, generally, has inhibitory effects on germination of seeds (Zhang, 2010; Kaveh, 2011; El-Sabagh, 2018) due to hyperosmotic stress and hyper-ionic toxicity (Hasegawa 2000). Similar tend was observed in dry weight as salt concentration was increased. No much reduction in dry weight was seen at $25 \mathrm{mM}$ salt concentration i.e. $25 \mathrm{mM}$ was at par with control. In OL-10 dry weight decreased significantly from $21.8 \mathrm{mg}$ in control to $0 \mathrm{mg}$ at $200 \mathrm{mM}$ salt concentration level. In Kent decline in dry weight accounted for $2 \mathrm{mg}$ at $200 \mathrm{mM}$ salt level as compared to its control counterparts.

\section{Lamina Length (cm)}

Lamina growth decreases with increased salinity level. Differential response was seen at 75,100 an $\mathrm{d} 125 \mathrm{mM} \mathrm{NaCl}$ concentration. The decline in lamina length range varied from 12.6 percent to 82.4 percent from 75 to $100 \mathrm{mM}$ salt concentrations in different oat genotypes.

In comparatively sensitive genotypes, the decrease was more than 60 percent. In moderate genotypes the range lied between 30 to 60 percent whereas in salt tolerant genotypes, the decline was less than 30 percent. With a 97 percent decline at $200 \mathrm{mM}$ as compared to control, salt stress was much pronounced in lamina length. Much differential effects were observed at $75 \mathrm{mM}$ and $100 \mathrm{mM} \mathrm{NaCl}$ where a sudden decrease in length of lamina was observed in many genotypes. At $125 \mathrm{mM}$ much of lamina growth was diminished in most of the genotypes. In In OL-10 a tremendous decrease of 60.5 percent at $100 \mathrm{mM}$ was seen thus making it most sensitive among all the 8 genotypes. Kent was considered as most salt tolerant with a mere decrease of only 29.3 percent at 100 $\mathrm{mM} \mathrm{NaCl}$ concentration.

\section{Sheath}

A structure at the base of a leafs petiole that partly surrounds or protect the stem or another organ that it subtends. Sheath, but not root or leaf, were useful as indicators to identify salt stress. The results showed that the Sheath length also reduced gradually with the increase in salt concentration but the decline 
was not very much pronounced. Sheath length showed a decline in all the genotypes. In OL10 genotype sheath length declined by 37.5 percent at $100 \mathrm{mM}$ and in Kent it declined by 27.5 percent at $100 \mathrm{mM}$. (De Leon et al., 2015) reported that salinity tolerance is most likely controlled in the shoot.

\section{Dry weight (mg)}

Similar trend was observed in dry weight as salt concentration was increased. No much reduction in dry weight was seen at $25 \mathrm{mM}$ $\mathrm{NaCl}$ concentration i.e. $25 \mathrm{mM}$ was at par with control. In OL-10 dry weight decreased significantly from $21.8 \mathrm{mg}$ in control to $0 \mathrm{mg}$ at $200 \mathrm{mM}$ salt concentration level. In Kent decline in dry weight accounted for $2 \mathrm{mg}$ at $200 \mathrm{mM}$ salt level as compared to its control counterparts.

Table.1 Salt stress effect on percent germination in oat (Avena sativa L.)

\begin{tabular}{|c|c|c|c|c|c|c|c|c|}
\hline Treatment & OL-10 & Kent & OL-1862 & OL-1895 & OL-1966 & OL-125 & OL-1869 & OL-1876 \\
\hline Control & 90 & 100 & 95 & 83 & 100 & 91.6 & 96.6 & 100 \\
\hline $\mathrm{NaCl}(25 \mathrm{mM})$ & 71 & 100 & 90 & 78.3 & 100 & 90 & 96.6 & 98.3 \\
\hline $\mathrm{NaCl}(50 \mathrm{mM})$ & 65 & 95 & 85 & 75 & 100 & 87.3 & 88 & 90 \\
\hline $\mathrm{NaCl}(75 \mathrm{mM})$ & 65 & 84.3 & 75 & 75 & 96 & 81.6 & 81.6 & 80 \\
\hline $\mathrm{NaCl}(100 \mathrm{mM})$ & 49.3 & 80 & 61 & 74 & 60 & 61.6 & 53.3 & 75 \\
\hline $\mathrm{NaCl}(125 \mathrm{mM})$ & 48.7 & 70 & 35 & 44 & 50 & 60 & 39.3 & 70.6 \\
\hline $\mathrm{NaCl}(150 \mathrm{mM})$ & 0 & 58.3 & 25 & 35 & 47.3 & 51.6 & 23.3 & 70 \\
\hline $\mathrm{NaCl}(175 \mathrm{mM})$ & 0 & 45.7 & 20.3 & 30 & 23.3 & 36.6 & 0 & 55 \\
\hline $\mathrm{NaCl}(200 \mathrm{mM})$ & 0 & 26.7 & 20 & 17.6 & 0 & 0 & 0 & 28.3 \\
\hline CD at $5 \%$ & \multicolumn{8}{|c|}{$X=2.22$} \\
\hline
\end{tabular}

$\mathrm{X}=$ Genotype

$\mathrm{Y}=$ Salt Concentration

Table.2 Salt stress effect on shoot length in oat (Avena sativa L.)

\begin{tabular}{|l|c|c|c|c|c|c|c|c|}
\hline Shoot length(cm) & & & & & & & \\
\hline Treatment & OL-10 & Kent & OL-1862 & OL-1895 & OL-1966 & OL-125 & OL-1869 & OL-1876 \\
\hline Control & 16.3 & 17.6 & 16.8 & 18.9 & 21.1 & 16.8 & 16.1 & 16.0 \\
\hline $\mathbf{N a C l}(\mathbf{2 5 m M})$ & 15.1 & 16.1 & 13.9 & 16.9 & 16.0 & 14.7 & 8.1 & 13.7 \\
\hline $\mathbf{N a C l}(\mathbf{5 0 m M})$ & 14.1 & 14.3 & 12.1 & 14.7 & 12.3 & 13.7 & 7.7 & 13.0 \\
\hline $\mathbf{N a C l}(\mathbf{7 5 m M})$ & 11.0 & 14.3 & 12.3 & 14.0 & 9.1 & 11.8 & 7.4 & 11.9 \\
\hline $\mathbf{N a C l}(\mathbf{1 0 0 m M})$ & 6.8 & 10.8 & 8.7 & 11.2 & 5.5 & 6.6 & 5.4 & 9.8 \\
\hline $\mathbf{N a C l}(\mathbf{1 2 5 m M})$ & 2 & 8.5 & 5.6 & 9.5 & 5.2 & 3.7 & 5.0 & 7.5 \\
\hline $\mathbf{N a C l}(\mathbf{1 5 0 m M})$ & 0 & 5.7 & 4.5 & 6.9 & 3.6 & 3.1 & 2.7 & 5.0 \\
\hline $\mathbf{N a C l}(\mathbf{1 7 5 m M})$ & 0 & 4.4 & 3.4 & 2.7 & 2.1 & 2.3 & 0.0 & 2.7 \\
\hline $\mathbf{N a C l}(\mathbf{2 0 0 m M})$ & 0 & 3.4 & 2.0 & 2.3 & 0.0 & 0.0 & 0.0 & 1.5 \\
\hline $\mathbf{C D} \mathbf{a t} \mathbf{5 0}$ & & & \multicolumn{2}{|c|}{$\mathrm{A}=0.57$} & $\mathrm{~B}=0.29$ & $\mathrm{AB}=0.82$ & & \\
\hline
\end{tabular}


Table.3 Salt stress effect on root length $(\mathrm{cm})$ in oat (Avena sativa L.)

\begin{tabular}{|c|c|c|c|c|c|c|c|c|}
\hline $\begin{array}{l}\text { Root } \\
\text { length(cm) }\end{array}$ & & & & & & & & \\
\hline Treatment & OL-10 & Kent & OL-1862 & OL-1895 & OL-1966 & OL-125 & OL-1869 & OL-1876 \\
\hline Control & 10.2 & 12.3 & 11.7 & 11.4 & 13.3 & 14.5 & 9.1 & 101.5 \\
\hline $\mathrm{NaCl}(25 \mathrm{mM})$ & 9.4 & 11.2 & 9.4 & 8.8 & 10.2 & 11.6 & 8 & 11.3 \\
\hline $\mathrm{NaCl}(50 \mathrm{mM})$ & 9.4 & 9 & 9 & 7.7 & 9.6 & 11.6 & 7.9 & 11 \\
\hline $\mathrm{NaCl}(75 \mathrm{mM})$ & 7.4 & 9 & 8.5 & 7.2 & 7.4 & 13.1 & 7.7 & 10 \\
\hline $\mathrm{NaCl}(100 \mathrm{mMO}$ & 6.5 & 8.8 & 6.5 & 5 & 6.9 & 6.1 & 7.5 & 8.5 \\
\hline $\mathrm{NaCl}(125 \mathrm{mM})$ & 4.3 & 7.5 & 6.3 & 4.4 & 5.9 & 6.1 & 6.5 & 8.5 \\
\hline $\mathrm{NaCl}(150 \mathrm{mM})$ & 0 & 6 & 4.7 & 3.7 & 5.2 & 6.0 & 5.8 & 6 \\
\hline $\mathrm{NaCl}(175 \mathrm{mM})$ & 0 & 4.6 & 2.6 & 3.1 & 3.2 & 4.4 & 0 & 5.5 \\
\hline $\mathrm{NaCl}(200 \mathrm{mM})$ & 0 & 4.0 & 2.4 & 1.4 & 0 & 0 & 0 & 3.3 \\
\hline CD at $5 \%$ & \multicolumn{4}{|c|}{$X=0.47$} & $=0.50$ & $K Y=1.42$ & & \\
\hline
\end{tabular}

$\mathrm{X}=$ Genotype

$\mathrm{Y}=$ Salt Concentration

Table.4 Effect of salt stress on percent decrease in Lamina length in oat (Avena sativa L.) variety

\begin{tabular}{|l|r|r|r|r|r|r|r|r|}
\hline \% decrease & & & & & & & \\
\hline Lamina & OL-10 & \multicolumn{1}{|c|}{ Kent } & OL-1862 & OL-1895 & OL-1966 & OL-125 & OL-1869 & OL-1876 \\
\hline Control & 0 & 0 & 0 & 0 & 0 & 0 & 0 & 0 \\
\hline $\mathbf{2 5 m M}$ & 18.3 & 10.9 & 26.7 & 11.5 & 28.6 & 10.7 & 64.1 & 31.8 \\
\hline $\mathbf{5 0 m M}$ & 30.6 & 26.4 & 16.9 & 25 & 25.1 & 31.5 & 65.8 & 15 \\
\hline $\mathbf{7 5 m M}$ & 47.6 & 27.5 & 32 & 61.5 & 12.6 & 33.8 & 85.8 & 39.8 \\
\hline $\mathbf{1 0 0} \mathbf{m M}$ & 60.5 & 29.3 & 56.2 & 71.1 & 82.4 & 69.2 & 61.6 & 29.2 \\
\hline $\mathbf{1 2 5} \mathbf{m}$ & 67.3 & 48.2 & 70.5 & 71.1 & 84.2 & 86.1 & 95.8 & 55.7 \\
\hline $\mathbf{1 5 0} \mathbf{m}$ & 100 & 81.6 & 83 & 90.3 & 92.3 & 89.2 & 76.6 & 85.8 \\
\hline $\mathbf{1 7 5} \mathbf{m}$ & 100 & 82.2 & 89.5 & 90.3 & 95.3 & 96.9 & 100 & 92 \\
\hline $\mathbf{2 0 0} \mathbf{m}$ & 100 & 89 & 89.5 & 100 & 100 & 100 & 100 & 100 \\
\hline
\end{tabular}

Table.5 Effect of salt stress on percent decrease in sheath length in oat (Avena sativa L.) variety

\begin{tabular}{|l|r|r|r|r|r|r|r|r|}
\hline Sheath & OL-10 & \multicolumn{1}{|c|}{ Kent } & OL-1862 & OL-1895 & OL-1966 & OL-125 & OL-1869 & OL-1876 \\
\hline Control & 0 & 0 & 0 & 0 & 0 & 0 & 0 & 0 \\
\hline $\mathbf{2 5 m M}$ & 3.5 & 17.3 & 6.7 & 2 & 0 & 0 & 19.6 & 2 \\
\hline $\mathbf{5 0 m M}$ & 5.3 & 21.7 & 20.3 & 8 & 10.7 & 11.3 & 27.4 & 14.5 \\
\hline $\mathbf{7 5 m M}$ & 19.6 & 24.6 & 18.6 & 12 & 16 & 28.3 & 29.4 & 20.8 \\
\hline $\mathbf{1 0 0 m M}$ & 37.5 & 27.5 & 30.5 & 12 & 35.7 & 58.4 & 45 & 27 \\
\hline $\mathbf{1 2 5 m M}$ & 53.5 & 27.5 & 30.5 & 12 & 55.3 & 62.2 & 66.6 & 45.8 \\
\hline $\mathbf{1 5 0 m M}$ & 100 & 49.2 & 54.2 & 26 & 55.3 & 62.2 & 86.2 & 58.3 \\
\hline $\mathbf{1 7 5 m M}$ & 100 & 63.7 & 69.4 & 46 & 67.8 & 75.4 & 100 & 72.9 \\
\hline $\mathbf{2 0 0 m M}$ & 100 & 75.3 & 74.5 & 60 & 100 & 100 & 100 & 85.4 \\
\hline
\end{tabular}


Table.6 Salt stress effect on dry weight (mg) in oat (Avena sativa L.)

\begin{tabular}{|l|c|c|c|c|c|c|c|c|}
\hline Dry weight & & & & & & & \\
\hline Treatment & OL-10 & Kent & OL-1862 & OL-1895 & OL-1966 & OL-125 & OL-1869 & OL-1876 \\
\hline Control & 21.8 & 36 & 26 & 45.3 & 34.6 & 25.7 & 27.7 & 45.4 \\
\hline $\mathbf{N a C l}(\mathbf{2 5 m M})$ & 20 & 23.3 & 17 & 25.8 & 32 & 21.3 & 26 & 45 \\
\hline $\mathbf{N a C l}(\mathbf{5 0 m M})$ & 16 & 19.5 & 15.9 & 25 & 27.9 & 20 & 26 & 42 \\
\hline $\mathbf{N a C l}(\mathbf{7 5 m M})$ & 7.8 & 18.3 & 9.6 & 21.5 & 23.7 & 20 & 25.7 & 32.4 \\
\hline $\mathbf{N a C l}(\mathbf{1 0 0 m M 0}$ & 6.4 & 15 & 7.6 & 21 & 23 & 16.3 & 24.7 & 26.5 \\
\hline $\mathbf{N a C l}(\mathbf{1 2 5 m M})$ & 6 & 8.9 & 7 & 4.5 & 21 & 16.3 & 11.6 & 24.6 \\
\hline $\mathbf{N a C l}(\mathbf{1 5 0 m M})$ & 0 & 4.7 & 2 & 4 & 5.8 & 13 & 7.5 & 21.6 \\
\hline $\mathbf{N a C l}(\mathbf{1 7 5 m M})$ & 0 & 4.7 & 1.5 & 3.5 & 2 & 5.7 & 0 & 11.5 \\
\hline $\mathbf{N a C l}(\mathbf{2 0 0 m M})$ & 0 & 2 & 0 & 1.8 & 0 & 0 & 0 & 11.3 \\
\hline $\mathbf{C D}$ at 5\% & & & & $\mathrm{X}=0.53$ & $\mathrm{Y}=0.56$ & $\mathrm{XY}=1.60$ & & \\
\hline
\end{tabular}

$\mathrm{X}=$ Genotype, $\mathrm{Y}=\mathrm{NaCl}$ concentration

Table.7 Effect of salt stress on seed vigour I

\begin{tabular}{|l|c|c|c|c|c|c|c|c|}
\hline Seed Vigour(I) & & & & & & & \\
\hline Treatment & OL-10 & Kent & OL-1862 & OL-1895 & OL-1966 & OL-125 & OL-1869 & OL-1876 \\
\hline Control & 2433 & 2930 & 2714 & 2267.7 & 3436.7 & 2864.3 & 2437.3 & 2743.3 \\
\hline $\mathbf{N a C l}(\mathbf{2 5 m M})$ & 1873.9 & 2726.7 & 2097 & 1930 & 2620 & 2365.8 & 1552.7 & 2461.7 \\
\hline $\mathbf{N a C l}(\mathbf{5 0 m M})$ & 1529.8 & 2215.8 & 1789.4 & 1862.3 & 2190 & 2208.1 & 1374.8 & 2163 \\
\hline $\mathbf{N a C l}(\mathbf{7 5 m M})$ & 1283 & 1960.0 & 1458.2 & 1659.5 & 1584.9 & 2023.8 & 1232.8 & 1819.2 \\
\hline $\mathbf{N a C l}(\mathbf{1 0 0 m M})$ & 750.2 & 1567.2 & 811.0 & 1193.6 & 743.5 & 788.5 & 685.7 & 1461.3 \\
\hline $\mathbf{N a C l}(\mathbf{1 2 5 m M})$ & 309.5 & 1117.7 & 412.8 & 610.7 & 556.8 & 606.2 & 452.4 & 1181.3 \\
\hline $\mathbf{N a C l}(\mathbf{1 5 0 m M})$ & 0 & 683.8 & 229.8 & 372.8 & 415.6 & 472.5 & 195.3 & 796 \\
\hline $\mathbf{N a C l}(\mathbf{1 7 5 m M})$ & 0 & 414 & 124.7 & 174 & 123.7 & 245 & 0 & 492.2 \\
\hline $\mathbf{N a C l}(\mathbf{2 0 0 m M})$ & 0 & 198.7 & 86.8 & $\mathbf{5 9 . 9}$ & 0 & 0 & 0 & 127 \\
\hline & & \multicolumn{2}{|c|}{$\mathbf{A = 5 6 . 9}$} & $\mathbf{B = 6 0 . 4}$ & $\mathbf{A B = 1 7 0 . 9}$ & & & \\
\hline
\end{tabular}

$\mathrm{X}=$ Genotype

$\mathrm{Y}=\mathrm{NaCl}$

Table.8 Effect of salt stress on seed vigour II

\begin{tabular}{|l|c|c|c|c|c|c|c|c|}
\hline Seed Vigour(II) & & & & & & & \\
\hline Treatment & OL-10 & Kent & OL-1862 & OL-1895 & OL-1966 & OL-125 & OL-1869 & OL-1876 \\
\hline Control & 2 & 3.6 & 2.3 & 3.3 & 3.4 & 2.3 & 2.6 & 4.5 \\
\hline NaCl(25mM) & 1.4 & 2.3 & 1.5 & 1.9 & 3.2 & 1.9 & 2.5 & 4.4 \\
\hline $\mathbf{N a C l}(\mathbf{5 0 m M})$ & 1 & 1.8 & 1.3 & 2.0 & 2.7 & 1.7 & 2.2 & 3.7 \\
\hline $\mathbf{N a C l}(\mathbf{7 5 m M})$ & 0.5 & 1.4 & 0.7 & 1.7 & 2.3 & 1.6 & 2.0 & 2.5 \\
\hline $\mathbf{N a C l}(\mathbf{1 0 0 m M})$ & 0.3 & 1.2 & 0.3 & 1.4 & 1.4 & 1 & 1.3 & 1.9 \\
\hline $\mathbf{N a C l}(\mathbf{1 2 5 m M})$ & 0.3 & 0.6 & 0.2 & 0.1 & 1 & 1.0 & 0.4 & 1.7 \\
\hline $\mathbf{N a C l}(\mathbf{1 5 0 m M})$ & 0 & 0.2 & 0 & 0.1 & 0.2 & 0.4 & 0.1 & 1.5 \\
\hline $\mathbf{N a C l}(\mathbf{1 7 5 m M})$ & 0 & 0.1 & 0 & 0.1 & 0.0 & 0.2 & 0 & 0.7 \\
\hline $\mathbf{N a C l}(\mathbf{2 0 0 m M})$ & 0 & 0 & 0 & 0.0 & 0 & 0 & 0 & 0.3 \\
\hline $\mathbf{C D}$ at 5\% & & & $\mathrm{A}=0.69$ & & $\mathrm{~B}=0.73$ & $\mathrm{AB}=0.20$ & & \\
\hline
\end{tabular}




\section{Seed vigour index (SVI) I and II}

Seed vigour is a physiological property which governs the capability of a seed to produce a seedling quickly in soil and the extent to which that seed tolerate a different environmental factors (Perry, 1980). Perry (1972b) concluded that seeds which have high vigour are more tolerant to environmental stress. The deleterious effects of salinity were further confirmed by analyzing vigour index. According to Table 6, in OL-10, 2433 was recorded vigour I in control, 750.2 at $100 \mathrm{mM}$ and 0 at $200 \mathrm{mM}$ salt concentration. Seed vigour is a physiological property which governs the capability of a seed to produce a seedling quickly in soil and the extent to which that seed tolerate a different environmental factors (Perry, 1980). Perry (1972b) concluded that seeds which have high vigour are more tolerant to environmental stress. The deleterious effects of salinity were further confirmed by analyzing vigour index.

The outcome of this study showed that the maximum percentage germination was recorded in control conditions and minimum at $150 \mathrm{mM}$ salinity level; however, no germination occurred at higher salinity levels $(200 \mathrm{mM})$ in some varieties. Increased salinity caused a significant reduction in germination percentage, germination rate, root and shoot length and fresh weight of root and shoot (ElShaieny, 2015). Growth arrest in plants during the early stage of salt stress is mostly due to salt-induced osmotic stress (Sobhanian et al., 2010, Munns, 2011, Carassay et al., 2012). Salt stress affects not only oat plant morphological, physiological processes but also germination of seed, growth and water/nutrient uptake (Willenborg et al., 2004). (Tajbakhsh et al., 2006) reported that selection of crop plants for salinity stress at germination stage is essential for determining salt tolerance potential of crops, since this stage mostly determines crop establishment. (Balkan et al., 2015) also observed that germination is moderately delayed by salinity stress and this may the result of seed having a lower water uptake at high salinity levels due to osmotic stress.

Similarly, with increasing salinity seed vigor index also declines (Table 6). These findings also correlated with the findings of (Kader and Jutzi 2004) and they observed that with increase in salinity levels seed characteristics were decreased. (Keshavarzi et al., 2011) also found the similar results and reported the impact of ions on declining the germination parameter.

There was a significantly decreased in the result of the root, shoot length of the studied plant under salt stress (Table 3 and Table 4). Length of root and shoot decreases with the increase in salinity level that may be due to slowing down the water absorption by the plants (Demir and Arif, 2003). Moreover, (Jamil et al., 2006) observed that salt stress inhibited largely plant growth and this may be because of reduced supply of metabolites to young tissues because the production of this metabolite is significantly disturbed under the salt stress, either due to toxic effect of $\mathrm{NaCl}$ or low uptake of water. During salinity stress, less affected roots provide sufficient water and nutrients.

In this experiment the seedling fresh and dry weight of oat plant were decreased linearly with increasing salinity levels (Table 5 and Table 6). Decrease in fresh weight and dry weight has been seen in all plant tissues subjected to salt stress, but it is particularly noticeable in the aerial part. Salinity decrease plant growth through osmotic and toxic effects, and high sodium uptake ratio values cause sodicity, which increases soil resistance, decreases root growth, and reduces water movement through the root with a decrease in hydraulic conductivity (Table 7 and 8). 


\section{References}

Abdul-Baki A A and Anderson J D (1973) Vigor determination in soybean seed by multiple criteria. Crop Sci 13: 630-33.

Agami R A (2014) Applications of ascorbic acid or proline increase resistance to salt stress in barley seedlings. Biol Plant, 58(2): 34147.

Akbarimoghaddam M, Ghanbari A, Panjehkeh N (2011) Salinity effects on seed germination and seedling growth of bread wheat cultivars. Trakia J Sci., 9: 43-50.

Ashraf M and Harris P J C (2004) Potential biochemical indicators of salinity tolerance in plants. Plant Sci 166(199): 3-16.

Balkan A, Genctan T (2015) Response of rice (Oryza sativa L.) to salinity stress at germination and early seedling stages. $P a k$ J Agric Sci., 52(2):455-61.

Berk and Ozkan (2016) Determination of Responses of some Oat Cultivars (Avena sativa L.) to Salt and Drought Stress at the Germination Period. Department of Field Crops, Agriculture Faculty, Ankara University 31: 0254-23.

Carassay L R, Bustos D A, Golberg A D and Taleisnik E (2012) Tipburn in salt-affected lettuce (Lactuca sativa L.) plants results from local oxidative stress. $J$ Plant Physiol., 169(3): 285-93.

Chauhan A (2019) Influence of gibberellic acid and different salt concentrations on germination percentage and physiological parameters of oat cultivars. Saudi J Biol Sci 10:1319-62.

Chauhan A, Rajput N, Kumar D, Kumar A and Chaudhary A K (2016) Effect of different salt concentration on seed germination and seedling growth of different varieties of oat (Avena sativa L.). Int J Inf Res Rev 3: 2627-32.

Demir M and Arif IPEK (2003) Effects of different soil salinity levels on germination and seedling growth of safflower (Carthamus tinctorius L.). Turk J Agric For 27: 221-27.

El Sabagh A, Hossain A, Islam MS, Barutçular C, Fahad S, Ratnasekera D, Kumar N, Meena R S, Vera P and Saneoka H (2018) Role of osmoprotectants and soil amendments for sustainable soybean (Glycine max L.) production under drought condition: A review. J Exp Biol Agric Sci., 6: 32-41.

El-Shaieny (2015) Seed Germination percentage and early seedling establishment of five (Vigna unguiculata L. (Walp) genotypes under salt stress. Eur J Exp Biol 5: 22-32.

Gao Y, Lu Y, Wu M, Liang Y, Li Y, Zhang D (2016). Ability to remove $\mathrm{Na}^{+}$and retain $\mathrm{K}^{+}$correlates with salt tolerance in two maize inbred lines seedlings. Front Plant Sci 7:16-17.

Hasegawa P M, Bressan R A (2000) Plant cellular and molecular responses to high salinity. Annu Rev Plant Physiol Plant Mol Biol., 51: 463-99.

Hsiao T C, Xu L K (2000) Sensitivity of growth of roots versus leaves to water stress: biophysical analysis and relation to water transport. J Exp Bot., 51:1595-1616.

Jamil M, Lee D, Jung K Y, Ashraf M, Lee S C, Rha E S (2006) Effect of salt stress on germination and early seedling growth of four vegetables species. J Cent Eur Agric., 7: 273-82.

Kadar M A, Jutzi S C (2004) Effects of Thermal and Salt Treatments during Imbibition on Germination and Seedling Growth of Sorghum at $42 / 19^{\circ}$ C. J Agron Crop Sci., 190(1):35 - 8

Kaveh H, Nemati H, Farsi M and Jartoodeh S V (2011) How salinity affect germination and emergence of tomato lines. JBES 5: 15963.

Keshavarzi M H B (2011) Effect of Salt Stress on Germination and Early Seedling Growth of Savory (Satureja hortensis). Aust J Basic Appl Sci 5(12): 3274-79

Kumar M, Lee S C, Kim J Y, Kim S J, Aye S S and Kim S R (2014) Over-expression of dehydrin gene, OsDhn1, improves drought and salt stress tolerance through scavenging of reactive oxygen species in rice (Oryza sativa L.). J Plant Biol 57(2): 383-93.

Maas E V, Nieman R H (1978) Physiology of plant tolerance to salinity. In: Crop Tolerance and suboptimal land conditions 13: 277-99.

Memon S A, XiLin H and LiangJu W (2010) Morphological analysis of salt stress 
response of pak choi. Elect J Env Agricult Food Chem 9(1):248-54.

Mozafariyan M, Bayat K S A E and Bakhtiari S (2013) The effects of different sodium Chloride concentrations on the growth and photosynthesis parameters of tomato (Lycopersicum esculentum cv. Foria). Int J Agric Crop Sci 4(6): 203-07.

Munns (2011) Plant adaptations to salt and water stress. Adv Bot Res 57: 1-32.

Neto A D A, Prisco J T (2006) Effect of salt stress on antioxidative enzymes and lipid peroxidation in leaves and roots of salttolerant and salt-sensitive maize genotypes. Environ Exp Bot 56: 87-94.

Perry D A (1972b) Seed vigour and field establishment. Hortic Sci 42: 334-42.

Perry D A (1980). The concept of seed vigour and its relevance to seed production techniques In: Hebblethwaite PD ed. Seed production London Butter worths 12: 585-91

Prisco J T, Neto A, De C E B (2007) Effect of salt stress on Antioxidative enzymes and Lipid Peroxidation in Leaves and Roots of SaltTolerant and Salt-Sensitive Maize Genotypes. Environ Exp Bot 56: 87-94.

Ramezani E, Sepanlou M G and Badi H A N (2011). The effect of salinity on the growth, morphology and physiology Echium amoenum Fisc \& Mey. Afr $J$ Biotechnol 10(44): 8765-74.

Sobhanian H (2010) Salt Stress Responses of a Halophytic Grass Aeluropus lagopoides and Subsequent Recovery. Russ J Plant Physiol 57: 784-91.

Tajbakhsh M, Zhou M X, Chen Z H, Mendham N $\mathrm{H}$ (2006) Physiological and cytological response of salt-tolerant and non-tolerant barley to salinity during germination nd early growth. Aust J Exp Agric 46: 555-62
Talei D, Valdiani A, Yusop M K and Abdullah M $P$ (2013) Estimation of salt tolerance in Andrographis paniculata accessions using multiple regression model. Euphytica 189: 147-60.

Willenborg C J, Gulden R H, Johnson E N and Shirtliffe S J (2004) Germination characteristics of polymer-coated canola (Brassica napus L.) seeds subjected to moisture stress at different temperatures. $J$ Agron 96: 786-91.

Willenborg C J, Wildeman J C and Miller A K (2005) Oat germination characteristics differ among genotypes, seed sizes, and osmotic potentials. Crop Sci 45: 2023-29.

Zhang $\mathrm{H}$ and Zhou D (2010) The effects of salinity and osmotic stress on barley germination rate: sodium as an osmotic regulator. Ann Bot 106: 1027-35.

Zhang J R, Shan C, Rengel Z, Song Z B and Chen Q (2018) Phytomelatonin receptor PMTR1-mediated signaling regulates stomatal closure in Arabidopsis thaliana. $J$ Pineal Res $65: 12500$.

Zhang X, Wei L Q, Wang Z Z and Wang T (2013) Physiological and molecular features of Puccinellia tenuiflora tolerating salt and alkaline-salt stress. J Integr Plant Biol 55: 262-76.

Zhanwu G (2015) A noval system for evaluating drought-cold tolerance of grapevines using chlorophyll fluorescence. BMC Plant Biol 15: 82-92.

Zhao ShiXu, Wan Zhao, Ming Chen (2017) Genome-Wide Analysis of the RAV Family in Soybean and Functional Identification of GmRAV-03 Involvement in Salt and Drought Stresses and Exogenous ABA Treatment. Front Plant Sci 8: 90

\section{How to cite this article:}

Kamaljeet Kaur and Namarta Gupta. 2020. Physiological Parameters of Salt Tolerance in Different Genotypes of Oats (Avena sativa L.). Int.J.Curr.Microbiol.App.Sci. 9(09): 30413050. doi: https://doi.org/10.20546/ijcmas.2020.909.375 